\title{
BIOAEROSOLS EXPOSURE ASSESSMENT IN MOLD-DAMAGED HOUSES IN NORMANDY, FRANCE
}

\author{
ANTOINE DELANOE ${ }^{1}$, VIRGINIE SEGUIN ${ }^{1}$, VERONIQUE ANDRE ${ }^{1}$, STEPHANIE GENTE $^{1}$, \\ PHILIPPE VERITE ${ }^{1}$, EDWIGE VOTIER ${ }^{1}$, ESTELLE RICHARD ${ }^{1}$, VALERIE BOUCHART ${ }^{2}$, \\ MARGOT DELFOUR ${ }^{2}$, NATACHA HEUTTE ${ }^{3} \&$ DAVID GARON $^{1}$ \\ ${ }^{1}$ Normandie Univ., UNICAEN \& UNIROUEN, Centre F. Baclesse, \\ ABTE EA4651 - ToxEMAC, Caen \& Rouen, France \\ ${ }^{2} \mathrm{LABEO}, \mathrm{Caen}$, France \\ ${ }^{3}$ Normandie Univ., UNIROUEN, CETAPS EA3832, Rouen, France
}

\begin{abstract}
The deterioration of houses and indoor air quality caused by moisture and molds is a major health and economic concern in many countries. In 2009, the World Health Organization published a report that highlighted moisture problems in 10 to $50 \%$ of European homes. Damp indoor conditions lead to growth of microorganisms which can be released into the air. Airborne molds represent a significant part of these bioaerosols and are able to produce mycotoxins that may cause various adverse effects such as cytotoxicity or genotoxicity. This study follows 3 objectives: 1) characterization of airborne molds and selection of relevant microbiological indicators for monitoring air quality; 2) study of the toxicity of bioaerosols and molds collected from bioaerosols; 3 ) determination of the effects of climatic factors on fungal growth and mycotoxins production. Bioaerosols were collected in mold-damaged homes selected by local partners and then analyzed for their microbial composition (quantification of molds, endotoxins and glucans) and their toxicological properties (cytotoxicity on lung and skin cells). A questionnaire for assessing the health impact and the habits of residents was also systematically completed. Airborne mold concentrations ranged from 16.7 to $361,000 \mathrm{cfu} / \mathrm{m}^{3}$ and showed a fungal diversity ranging from 4 to 20 species per home. Aspergillus versicolor and Penicillium chrysogenum were the most recurrent species in bioaerosols. Fungal isolates belonging to the Aspergillus genus were tested in vitro for their ability to produce mycotoxins. Among them, sterigmatocystin and gliotoxin were found in A. versicolor and A. fumigatus cultures, respectively. The toxicological approach showed that some bioaerosols induce cytotoxic effects. This study was supported by the Conseil Régional de Normandie, the Agence Régionale de Santé de Normandie (ARS) and the Agence de l'Environnement et de la Maîtrise de l'Energie (ADEME).

Keywords: bioaerosols, cytotoxicity, endotoxins, glucans, indoor air, molds, mycotoxins.
\end{abstract}

\section{INTRODUCTION}

Mold-damaged buildings represent a serious problem as people spend up to $90 \%$ of their time indoor. In Europe, 10 to $50 \%$ of the buildings are considered to have moisture problem that can lead to mold proliferation and deterioration of materials [1]. Dampness and mold growth can be due to climatic factors (such as heavy rain or flooding), building defects (such as water leaks or insufficient ventilation), and are sometimes increased by inhabitant's habits [2].

The microbial contents of the air in these buildings, also named bioaerosols, need to be more precisely characterized, and their impact on the human health are not fully elucidated [1]. Among the components of bioaerosols, fungal particles represent a significant part that is known to cause a variety of health effects including asthma aggravation or chronic respiratory affections [3]. Some molds like Aspergillus fumigatus are also able to cause infections on immunodeficient people [4]. In addition, many molds can produce mycotoxins in the indoor environment [5], [6].

Bioaerosols also contain other microbiological components. $\beta$-Glucans occur in the cell wall of fungi, plants and few bacteria. Endotoxins are parts of the cell wall of Gram-negative 
bacteria, which are released during cellular lysis. Endotoxins and $\beta$-Glucans have been shown to be able to induce inflammatory responses and to cause respiratory symptoms [7]-[9].

Our study proposes a global approach to investigate indoor bioaerosols and to assess human exposure.

\section{MATERIALS AND METHODS}

This study was based on the investigation of 41 mold-damaged dwellings ( 25 apartments and 16 houses), selected by local partners: The Service Communal d'Hygiène et de Santé de la Ville de Caen (SCHS), the Conseillers Médicaux en Environnement Intérieur (CMEI) and tenant's associations. Most of these homes showed insufficient ventilation, building defects or water leaks.

\subsection{Sampling of bioaerosols}

In each home, bioaerosols were collected in the middle of the living room at 1-meter height. Air was sampled during 40 minutes using a biocollector Coriolis $\mu^{\circledR}$ (Bertin Technologies, France) with a flow rate of $300 \mathrm{l} / \mathrm{min}$. Airborne microorganisms were collected in sterile water containing $0.02 \%$ Tween 80 . Physical characteristics (particles number in 15 channels from 0.3 to $20 \mu \mathrm{m}$, relative humidity $<95 \%$ and temperature 0 to $+40{ }^{\circ} \mathrm{C}$ ) were monitored every 6 seconds using a portable aerosol spectrometer (Model 1.108, Grimm Technologies, Inc., Douglasville GA, USA).

Endotoxins and $\beta$-glucans were quantified from the collection liquid using the Endosafe LAL test (Charles River Laboratories).

\subsection{Fungal characterization of bioaerosols}

For each bioaerosol, $1 \mathrm{ml}$ of collection liquid and dilutions up to $10^{-3}$, were deposited into triplicate plates, and malt extract (1.5\%) agar (1.5\%) (MEA) (Merck, Germany) supplemented with chloramphenicol $(0.02 \%)$ was poured. The plates were incubated at $25^{\circ} \mathrm{C}$ for 7 days and were daily checked. The resulting colonies were counted, purified and reported as Colonies Forming Units (CFU) per $\mathrm{m}^{3}$. Identification was carried using macroscopic and microscopic features following the previous studies [6], [10]-[17] and the sequencing of ITS region and $\beta$-tubulin gene as necessary.

\subsection{Toxinogenic potential of fungal isolates}

A total of 40 purified isolates belonging to the Aspergillus genus (Table 1) were analyzed for their ability to produce 24 mycotoxins in vitro as described in previous study [18]. Fungal strains were cultured during 14 days on MEA medium. For each dish, 3 agar plugs measuring 8 millimeters in diameter were removed from central area of the colony (including conidia and mycelium), pooled, weighted and transferred to $5 \mathrm{ml}$ glass. Mycotoxins were extracted with $2 \mathrm{ml}$ of ethyl acetate acidified by acetic acid. After centrifugation (15 $\mathrm{min}$ at 1,500 rpm), each extract was evaporated to dryness under a stream of nitrogen. The final residue was dissolved in acetonitrile and filtered on a Millex $0.45 \mu \mathrm{m}$ PVDF filter (Merck Millipore, Billerica, MA, USA) before injection into HPLC-MS/MS.

Mycotoxins were quantified by high performance liquid chromatography coupled to mass spectrometry (HPLC-MS/MS) in multiple reaction monitoring (MRM) mode. Liquid chromatography was performed using an Agilent Technologies 1200 HPLC system coupled to a triple quadrupole mass spectrometer (6460 series, Agilent Technologies, Santa Clara, 
CA, USA) equipped with an electrospray interface, operated in the positive and negative modes. The MassHunter B.02.00 software was used for data processing.

\subsection{Cytotoxicity of bioaerosols}

All of the 41 bioaerosols were tested against A549 pulmonary cells (ATCC ${ }^{\circledR}$ CRM-CLL$185^{\mathrm{TM}}$ ) and HaCaT skin cells (AddexBio Catalog No. T0020001). A $5 \mathrm{ml}$ aliquot of the collecting liquid was evaporated under $400 \mathrm{mbar}$ in an EZ-2 Genevac (SP Scientific, Ipswich, United Kingdom). Pellets were dissolved in $1 \mathrm{ml}$ of Dulbecco's Modified Eagle's medium (DMEM) with 10\% fetal bovine serum (Pan Biotech, Germany).

Cells were exposed during $24 \mathrm{~h}$ to these concentrated bioaerosols $(200 \mu \mathrm{L})$, using a $96-$ wells plate (4 replicates/bioaerosol).

Cell survival was evaluated using the Sulforhodamine B assay [19]. Absorbance was read using a spectrophotometer at $570 \mathrm{~nm}$.

\section{RESULTS AND DISCUSSION}

\subsection{Characteristics of the dwellings}

Our study investigated 41 bioaerosols from mold-damaged homes located in Normandy (France), and contributed to a better understanding of airborne microbial contaminants. Among the studied building, $46 \%$ were in urban areas, $39 \%$ in suburban areas and $15 \%$ in rural areas. Eighty five percent of these dwellings were leased and $15 \%$ were occupied by owners.

Observed indoor temperatures varied from 17.4 to $26.1{ }^{\circ} \mathrm{C}$, with a mean value of $21.5^{\circ} \mathrm{C}$ in spring, $23.6^{\circ} \mathrm{C}$ in summer, $22.3^{\circ} \mathrm{C}$ in autumn and $21.0^{\circ} \mathrm{C}$ in winter. Relative humidity ranged from 44.8 to $74.3 \%$, with a mean value of $60.6 \%$ and a median value of $60.5 \%$. Total particles between 0.3 and $20 \mu \mathrm{m}$ varied from $7.8 \times 10^{6}$ to $2.0 \times 10^{9}$ particles per $\mathrm{m}^{3}$ of air, with a mean value of $1.2 \times 10^{8}$. A higher number of particles was found between 0.3 and 1 $\mu \mathrm{m}$ in size (Fig. 1) which could suggest the presence of fungal fragments in moldy homes as described by Reponen et al. [20].

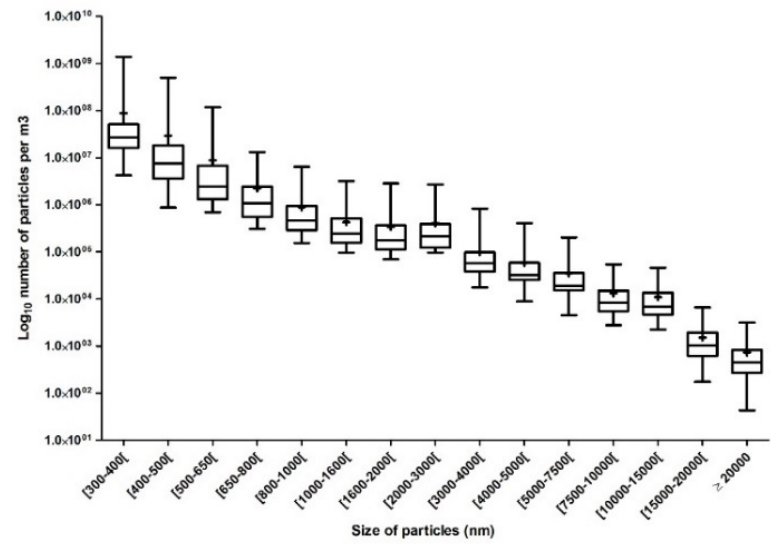

Figure 1: Number of particles per $\mathrm{m} 3$ of air between 0.3 and $20 \mu \mathrm{m}$ counted in the 41 homes. Whiskers' boxplots indicate minimum and maximum. 


\subsection{Fungal characterization of bioaerosols}

Total viable fungi varied from $1.67 \times 10^{1}$ from $3.61 \times 10^{5} \mathrm{cfu} / \mathrm{m}^{3}$ of air. Twenty-seven of the 41 sampled houses showed contamination levels superior to $250 \mathrm{cfu} / \mathrm{m}^{3}$ of air, and 9 homes showed a fungal concentration higher than $1000 \mathrm{cfu} / \mathrm{m}^{3}$ of air (Fig. 2).

Recently, more and more interest has been showed to the microbial exposure of inhabitants of damaged homes or workplaces [21]. This study allowed the identification of 93 different species which can be classified in 31 genera. As described in another study using an impaction air sampler [22], Penicillium and Aspergillus were the most frequent genera, with respectively 38 and 13 different species identified from bioaerosols.

Among the species observed in our study, Penicillium chrysogenum and Aspergillus versicolor were the most recurrent strains. Other studies also found $A$. versicolor to be a common mold in damp houses using other sampling methods [22], [23]. This fungus is known for its ability to produce sterigmatocystin, a carcinogenic toxin [24], and an experimental exposure to spores of $A$. versicolor has shown to induce strong inflammatory effect on lung cell in mice [25]. For this last study, the first significant inflammatory effect was observed at a dose of $5 \times 10^{6}$ spores.

Endotoxins ranged from 0.14 to $91.13 \mathrm{ng} / \mathrm{m}^{3}$, with a mean value of $13.5 \mathrm{ng} / \mathrm{m}^{3}$, and a median value of $5.8 \mathrm{ng} / \mathrm{m}^{3}$ of air, while $\beta$-D-glucans were quantified from 0.16 to 15.48 $\mathrm{ng} / \mathrm{m}^{3}$, with a mean value of $1.51 \mathrm{ng} / \mathrm{m}^{3}$ and a median value of $1.0 \mathrm{ng} / \mathrm{m}^{3}$. Most of the endotoxins values were low and close to other published values [26]. Nevertheless 10 samples had an endotoxin level between 20 and $80 \mathrm{ng} / \mathrm{m}^{3}$ of air, which was considered by the Institut National de Recherche et de Sécurité (INRS) as an unsafe condition for daily exposure of 8 hours or more [27].

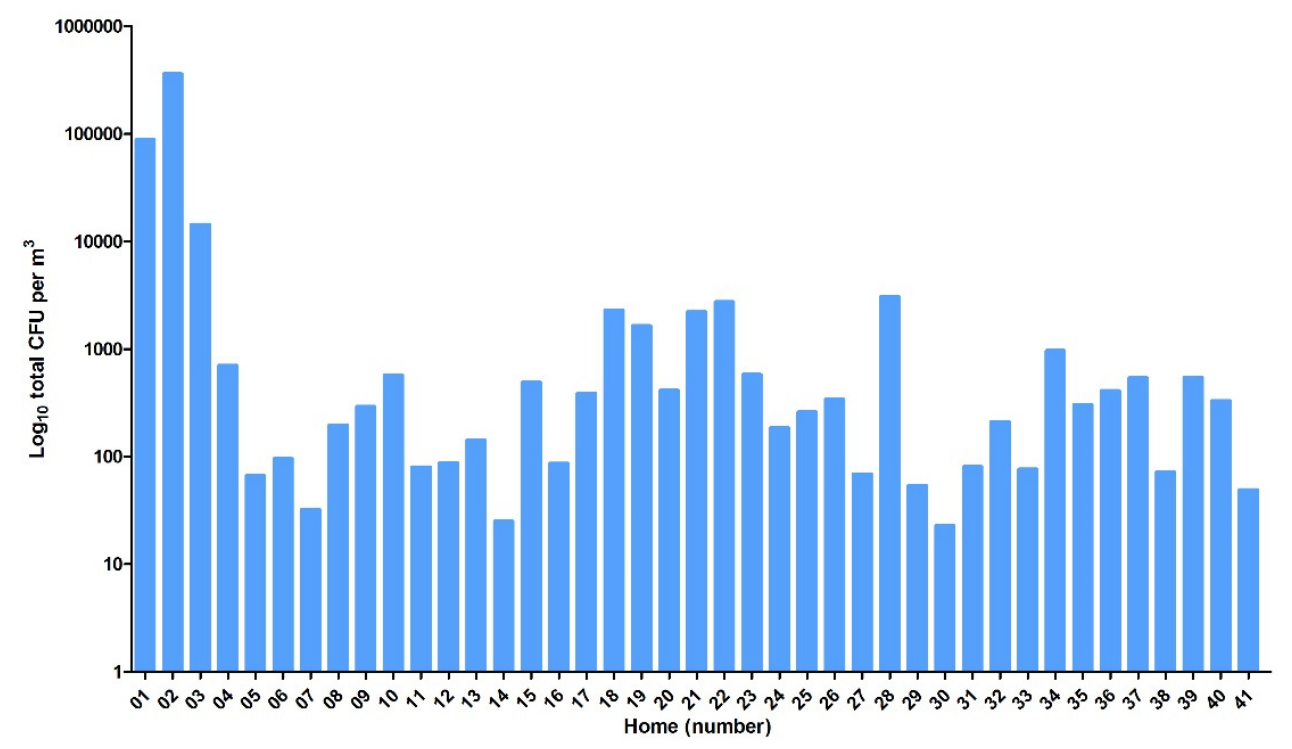

Figure 2: Total fungi contamination (expressed in cfu/m3 of air) for the 41 homes selected in this study. 


\subsection{Mycotoxins production by fungal isolates}

Among the 40 isolates of Aspergillus tested for their ability to produce mycotoxins, 31 strains were positive (Table 1).

Seven isolates of $A$. flavus produced cyclopiazonic acid, a mycotoxin that does not show potent acute toxicity in rodents [28]. None of the 8 isolates produced aflatoxins.

All the isolates of $A$. fumigatus produced verruculogen, 13 isolates produced fumagillin and 10 produced gliotoxin. While fumagillin is known for its amebicide and antifungal properties [29], gliotoxin was considered as a virulence factor in aspergillosis [30] and verruculogen induced modifications of electrophysiological properties in nasal epithelium cells [31]. Some isolates produced high concentrations of gliotoxin and verruculogen which could pose health risks to inhabitants if these mycotoxins were aerosolized.

One isolate of $A$. niger produced fumonisin $\mathrm{B} 2$, which is a rare phenomenon previously described by Frisvad [32].

Sterigmatocytin was secreted by all isolates of $A$. versicolor. Previous studies have shown frequent production of this mutagenic and cytotoxic mycotoxin by A. versicolor [33], [34].

Table 1: Mycotoxins production by Aspergillus isolates collected from bioaerosols in mold-damaged homes.

\begin{tabular}{|l|l|l|l|}
\hline Fungal species & Mycotoxins & $\begin{array}{l}\text { Number } \\
\text { of } \\
\text { positive } \\
\text { isolates }\end{array}$ & $\begin{array}{l}\text { Production } \\
\text { (min-max }) \\
\text { ng mycotoxin per g of } \\
\text { medium }\end{array}$ \\
\hline $\begin{array}{l}\text { Aspergillus } \\
\text { europaeus }\end{array}$ & - & $0 / 1$ & - \\
\hline Aspergillus flavus & $\begin{array}{l}\text { Cyclopiazonic } \\
\text { acid }\end{array}$ & $7 / 8$ & $3.4 \times 10^{1}-2.6 \times 10^{2}$ \\
\hline $\begin{array}{l}\text { Aspergillus } \\
\text { fumigatus }\end{array}$ & $\begin{array}{l}\text { Fumagillin } \\
\text { Gliotoxin } \\
\text { Verruculogen }\end{array}$ & $\begin{array}{l}13 / 15 \\
10 / 15\end{array}$ & $\begin{array}{l}3.9 \times 10^{1}-2.1 \times 10^{3} \\
15 \times 10^{0}-5.8 \times 10^{4} \\
1.8 \times 10^{0}-2.0 \times 10^{4}\end{array}$ \\
\hline $\begin{array}{l}\text { Aspergillus glaucus } \\
\text { Aspergillus melleus }\end{array}$ & - & $0 / 1$ & - \\
\hline $\begin{array}{l}\text { Aspergillus } \\
\text { montevidensis }\end{array}$ & - & $2 / 2$ & $4.5 \times 10^{2}-1.2 \times 10^{3}$ \\
\hline Aspergillus niger & Fumonisin B2 & $1 / 6$ & $1.7 \times 10^{2}$ \\
\hline $\begin{array}{l}\text { Aspergillus } \\
\text { pseudoglaucus }\end{array}$ & $\begin{array}{l}\text { Mycophenolic } \\
\text { acid }\end{array}$ & $3 / 3$ & $3.9 \times 10^{3}-4.0 \times 10^{3}$ \\
\hline $\begin{array}{l}\text { Aspergillus } \\
\text { versicolor }\end{array}$ & $\begin{array}{l}\text { Sterigmatocysti } \\
\mathrm{n}\end{array}$ & $3 / 3$ & $3.1 \times 10^{3}-5.0 \times 10^{4}$ \\
\hline
\end{tabular}




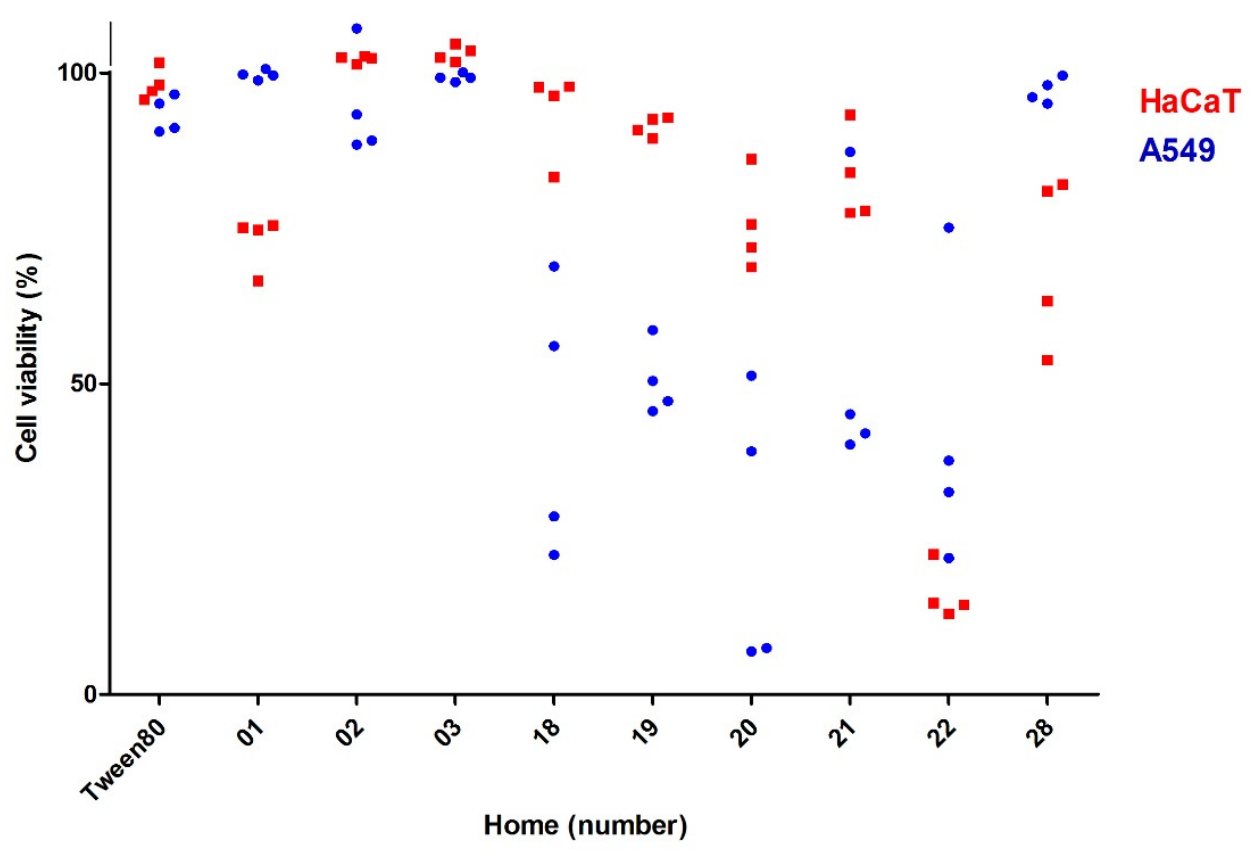

Figure 3: Cell survival (expressed in \% of cell viability compared to unexposed control) of the 9 most highly contaminated homes $(01,02,03,18,19,20,21,22$ and 28). Cell viability of collect liquid (Tween 80 at $0.02 \%$ ) is also displayed.

\subsection{Cytotoxicity of bioaerosols}

Bioaerosols showed different cytotoxic responses against the two cell lines (A549 and $\mathrm{HaCaT}$ ). The results corresponding to the most highly contaminated (more than $1000 \mathrm{cfu} / \mathrm{m}^{3}$ of air) homes $(\mathrm{n}=9)$ are showed in Fig. 3.

No cytotoxicity was observed for sterile collect liquid (Tween 80 ).

For some bioaerosols (homes 2 and 3), no cytotoxicity was observed on the two cell lines, while bioaerosol from home 22 highlighted a strong cytotoxicity and others bioaerosols (homes 19, 21 and 28) showed different responses according the cell type. These results suggested that the fungal contamination of bioaerosols was not the single factor that explained their cytotoxicity. Another study on cytotoxicity of air particles and fungal extracts showed similar results for aerosols [35].

\section{CONCLUSION}

Additional dwellings are currently investigated to complete our database and perform a statistical analysis. Evaluation of cytotoxicity will be completed by the screening of cytokines in cell supernatants. Assays in a climatic chamber are currently performed to better understand the conditions of fungal development and toxins production in indoor environment. 


\section{ACKNOWLEDGEMENTS}

This study was supported by the Conseil Régional de Normandie, the Agence Régionale de Santé de Normandie (ARS) and the Agence de l'Environnement et de la Maîtrise de l'Energie (ADEME).

\section{REFERENCES}

[1] WHO Europe (World Health Organization Europe). WHO Guidelines for Indoor Air Quality: Dampness and Mould, Copenhagen, pp. 1-228, 2009.

[2] Andersen, B., Frisvad, J.C., Søndergaard, I., Rasmussen, I.S. \& Larsen, L.S., Associations between Fungal Species and Water-Damaged Building Materials. Applied Environmental Microbiology, 77, pp. 4180-4188, 2011.

[3] Douwes, J., Thorne, P., Pearce, N. \& Heederik, D., Bioaerosol health effects and exposure assessment: progress and prospects. Annals of Occupational Hygiene, 47(3), pp. 187-200, 2003.

[4] Fisk, W.J., Lei-Gomez, Q. \& Mendell M.J., Meta-analyses of the associations of respiratory health effects with dampness and mold in homes. Indoor Air, 17 pp. 284 296, 2007.

[5] Jarvis, B.B., \& Miller, D.J., Mycotoxins as harmful air contaminants. Applied Microbiology Biotechnology, 66, pp. 367-372, 2005.

[6] Pottier, D. et al., Airborne molds and mycotoxins in Serpula lacrymans-damaged homes. Atmospheric Pollution Research, 5, pp. 325-334, 2014.

[7] Brigham, K.L. \& Meyrick, B., Endotoxin and lung injury. American Review of Respiratory Disease, 133, pp. 913-927, 1986.

[8] Piecková, E. \& Wilkins, K., Airway toxicity of house dust and its fungal composition. Annals of Agricultural and Environmental Medicine, 11, pp. 67-73, 2004.

[9] Rylander, R. \& Lin, R.H., (1-3)- $\beta$-D-glucan relationship to indoor air-related symptoms, allergy and asthma. Toxicology, 152, pp. 47-52, 2000.

[10] Booth, C., The Genus Fusarium, Commonwealth Mycological Institute, Kew, pp. 1237, 1966.

[11] Pitt, J.I., The Genus Penicillium and its Telemorphic States Eupenicillium and Talaromyces, Academic Press, London, pp. 1-629, 1979.

[12] Domsch, K.H., Gams, W. \& Anderson, T.H., Compendium of Soil Fungi, Academic Press, London, pp. 1-672, 1980.

[13] Von Arx, J.A., The Genus of Fungi Sporulating in Pure Culture, Cramer, Vaduz, pp. $1-315,1981$.

[14] Pitt, J.I., A Laboratory Guide to Common Penicillium Species, Food Science Australia, North Ryde, pp. 1-187, 2000.

[15] Klich, M.A., Identification of Common Aspergillus Species, Centraalbureau voor Schimmelcultures, Utrecht, United States, pp. 1-116, 2002.

[16] Samson, R.A., Hoekstra, E.S., Frisvad, J.C. \& Filtenborg, O., Introduction to Food and Airborne Fungi, Centraalbureau voor Schimmelcultures, Utrecht, United States, pp. 1-389, 2002.

[17] Samson, R.A. \& Friswad, J.C., Penicillium Subgenus Penicillium: New Taxonomic Schemes. Mycotoxins and other Extrolites, Centraalbureau voor Schimmelcultures, Utrecht, United States, pp. 1-260, 2004.

[18] Heutte, N. et al., Assessment of multi-contaminant exposure in a cancer treatment center: a 2-year monitoring of molds, mycotoxins, endotoxins, and glucans in bioaerosols. Environmental Monitoring Assessment, 189(31), pp. 1-14, 2017. 
[19] Vichai, V. \& Kirtikara, K., Sulforhodamine B colorimetric assay for cytotoxicity screening. Nature Protocols, 1, pp. 1112-1116, 2006.

[20] Reponen, T., Seo, S.C., Grimsley, F., Lee, T., Crawford, C. \& Grinshpun, S., Fungal fragments in moldy houses: a field study in homes in New Orleans and Southern Ohio. Atmospheric Environment, 41(37), pp. 8140-8149, 2007.

[21] Valkonen, M. et al., A. Microbial characteristics in homes of asthmatic and nonasthmatic adults in the ECRHS cohort. Indoor Air, 28(1), pp. 16-27, 2018.

[22] Dallongeville, A. et al., Concentration and determinants of molds and allergens in indoor air and house dust of French dwellings. Science of the Total Environment, 536, pp. 964-972, 2015.

[23] Beguin, H. \& Nolard, N., Mould biodiversity in homes I. Air and surface analysis of 130 dwellings. Aerobiologia, 10, pp. 157-166, 1994.

[24] Engelhart, S. et al., Occurrence of Toxigenic Aspergillus versicolor Isolates and Sterigmatocystin in Carpet Dust from Damp Indoor Environments. Applied and Environmental Microbiology, 68(8), pp. 3886-3890, 2002.

[25] Jussila, J., Komulainen, H., Kosma, V.M., Nevalainen, A., Pelkonen, J. \& Hirvonen, M.R., Spores of Aspergillus versicolor isolated from indoor air of a moisture-damaged building provoke acute inflammation in mouse lungs. Inhalation Toxicology, 14, pp. 1261-1277, 2002.

[26] Dales, R., Miller, D., Ruest, K., Guay, M. \& Judek, S., Airborne Endotoxin is associated with respiratory illness in the first 2 years of life. Environmental Health Perspectives, 114(4), pp. 610-614, 2006.

[27] INRS. Online, www.inrs.fr/risques/endotoxines-en-milieu-professionnel.html, 2015. Accessed on: 19 Feb. 2018.

[28] Burdock, G.A. \& Flamm, W.G., Review article: safety assessment of the mycotoxin cyclopiazonic acid. International Journal of Toxicology, 19, pp. 195-218, 2000.

[29] Zbidah, M., Lupescu, A., Jilani, K. \& Lang, F., Stimulation of Suicidal Erythrocyte Death by Fumagillin. Basic \& Clinical Pharmacology \& Toxicology, 112, pp. 346351, 2013.

[30] Sugui, J.A. et al., Gliotoxin Is a Virulence Factor of Aspergillus fumigatus: gliP Deletion Attenuates Virulence in Mice Immunosuppressed with Hydrocortisone. American Society for Microbiology 6(9), pp. 1562-1569, 2007.

[31] Khoufache, K. et al., Verruculogen associated with Aspergillus fumigatus hyphae and conidia modifies the electrophysiological properties of human nasal epithelial cells. BMC Microbiology, 7(5), 2007.

[32] Frisvad, J., Smedsgaard, J., Samson, R., Larsen, T. \& Thrane, U., Fumonisin B2 Production by Aspergillus niger. Journal of Agricultural and Food Chemistry, 55 pp. 9727-9732, 2007.

[33] Nielsen, K.F., Holm, G., Uttrup, L.P. \& Nielsen, P.A., Mould growth on building materials under low water activities. Influence of humidity and temperature on fungal growth and secondary metabolism. International Biodeterioration \& Biodegradation, 54, pp. 325-336, 2004.

[34] Schroeder, H.W. \& Kelton, W.H., Production of Sterigmatocystin by Some Species of the Genus Aspergillus and Its Toxicity to Chicken Embryos. Applied Microbiology, 30(4), pp. 589-591, 1975.

[35] Hirvonen, M. R., Huttunen, K. \& Roponen, M., Bacterial strains from moldy buildings are highly potent inducers of inflammatory and cytotoxic effects. Indoor Air, 15(9), pp. $65-70,2005$. 